\title{
ЗАСАДИ СТВОРЕННЯ ДЕРЖАВНОЇ СИСТЕМИ ІНФОРМАЦІЙНОГО МОНТТОРИНГУ ФАРМАЦЕВТИЧНОГО РИНКУ
}

\author{
Л. Ю. Бабінцева
}

\author{
Національна медична академія післядипломної освіти імені П. А. Шупика
}

\begin{abstract}
Запропоновано основні принципи інформаційного моніторингу та регулювання фармацевтичного ринку шляхом автоматизації процесів управління забезпеченості лікарськими засобами. До основи цих процесів покладено інформаційні технології. Розглянуто автоматизацію забезпечення медичних організацій і населення країни лікарськими засобами. Пропонується об'єднання існуючих баз даних і тих, що розробляються, в інтегровану систему баз даних на основі єдиних державних і галузевих класифікаторів.
\end{abstract}

Ключові слова: інформаційний моніторинг, система обігу лікарських засобів, автоматизація, державний нагляд, єдиний державний класифікатор.

\section{ПРИНЦИПЫ СОЗДАНИЯ ГОСУДАРСТВЕННОЙ СИСТЕМЫ ИНФОРМАЦИОННОГО МОНИТОРИНГА ФАРМАЦЕВТИЧЕСКОГО РЫНКА}

\author{
Л.Ю. Бабинцева \\ Национальная медицинская академия последипломного образования имени П. А. Шупика
}

\begin{abstract}
Предложены основные принципы информационного мониторинга и регулирования фармацевтического рынка путем автоматизации процессов управления обеспечения лекарственными средствами. В основу этих процессов положены информационные технологии. Рассмотрена автоматизация обеспечения медицинских организаций и населения страны лекарственными средствами. Предлагается объединение существующих баз данных и разрабатываемых в интегрированную систему баз данных на основе единых государственных и отраслевых классификаторов.
\end{abstract}

Ключевые слова: информационный мониторинг, система обращения лекарственных средств, автоматизация, государственный надзор, единый государственный классификатор.

\section{PRINCIPLES OF CREATION OF STATE SYSTEM OF INFORMATIVE MONITORING OF PHARMACEUTICAL MARKET}

L.Yu. Babintseva

\author{
National Medical Academy of Post-Graduate Education named after P. L. Shupyk
}

\begin{abstract}
Basic principles of the informative monitoring and adjusting of pharmaceutical market are offered by automation of processes of management of material well-being medicinal products. To basis of these processes information technologies are fixed. Automation of providing of medical organizations and population of country is considered by medicinal products. The association of existent databases and those that are developing as a part of one integrated system of databases on the basis of unified national and branch classifiers is suggested.
\end{abstract}

Key words: informative monitoring, system of turnover of medicinal products, automation, state supervision, unified national classifier.

Вступ. В Україні сьогодні в обігу знаходяться близько 13,0 тис. найменувань лікарських препаратів, 3 них 33,5 \% вітчизняного виробництва, 66,5 \% імпортного. Виробництво лікарських засобів (ЛЗ) здійснюється 141 фармацевтичним підприємствомвиробником.
В концепції розвитку фармацевтичної галузі України, що була прийнята на VI Національному з'їзді фармацевтів (2005р.), підкреслена необхідність іiі еволюційного розвитку, створення національної політики щодо пріоритетного забезпечення населення Л3, а також впровадження міжнародних стандартів належ-

(C) Л. Ю. Бабінцева 
ної виробничої, клінічної, лабораторної, дистриб'юторської, аптечної та інших практик [1].

Кінцевою метою реалізації концепції вважається збереження здоров'я населення шляхом забезпечення доступності до ефективних, безпечних та якісних ЛЗ.

Одним з найважливіших елементів концепції є створення єдиного інформаційного поля у фармації, основним завданням якого є забезпечення суб'єктів фармацевтичного ринку об'єктивною, оперативною, повною обгрунтованою, доказовою та доступною інформацією, що буде сприяти якісному медичному обслуговуванню населення.

Зрозуміло, що регулювання фармацевтичного ринку неможливе без інформаційного моніторингу шляхом автоматизації процесів управління забезпеченості лікарськими засобами.

Метою дослідження $є$ обгрунтування концепції інформаційної системи управління обігом лікарських засобів (ІСУОЛЗ).

Результати та їх обговорення. Відомості, отримані в результаті нагляду за фармацевтичною діяльністю і контролю над безпекою, ефективністю й якістю ЛЗ, є основою для об'єктивного аналізу ситуації у сфері обігу лікарських засобів.

Основні показники концепції системи, що пропонується:

- виключення дублювання введення інформації та підвищення іiі достовірності за рахунок ототожнення раніше введеної інформації;

- можливість обміну повідомленнями між територіально розподіленими компонентами;

- підвищення ефективності державного регулювання сфери обігу лікарських засобів;

- забезпечення автоматизованого інформаційного обміну між територіальними органами МОЗ України;

- організація взаємодії з інформаційними системами інших міністерств і відомств у рамках створення електронного уряду.

Створення IСУОЛЗ забезпечить ефективний моніторинг та оперативне прийняття управлінських рішень на основі аналізу накопиченої інформації, дозволить повною мірою здійснювати контрольно-наглядові функції за фармакологічною діяльністю медичних організацій.

ІСУОЛЗ повинна забезпечити: автоматизацію ведення реєстру лікарських засобів, виробів медичного призначення та медичної техніки, дозволених до застосування в Україні; персоніфікований облік призначення пацієнтам лікарських засобів у процесі надання медичної допомоги; персоніфікований облік відпуску лікарських засобів в аптечній мережі; облік закупівель і раціонального використання лікарських засобів, медичної техніки та виробів медичного призначення на всіх рівнях надання медичної допомоги. Окрім того, має бути автоматизація обліку інформації про побічну дію лікарських засобів; моніторинг цін на лікарські засоби і вироби медичного призначення; моніторинг імпорту/експорту лікарських засобів i виробів медичного призначення.

Для медичних організацій, що здійснюють фармацевтичну діяльність, система дозволить налагодити ефективний облік діяльності організації, надасть можливість своєчасно отримувати та використовувати інформацію про передові досягнення в області фармації. Для населення єдиний інформаційний банк даних ICУОЛЗ дозволить надавати кількісну й якісну інформацію про лікарські засоби.

На основі ІСУОЛЗ можливе також вирішення таких завдань:

1) забезпечення постійного та зручного доступу до розподілених інформаційних ресурсів системи, що сприятиме оперативному прийняттю рішень;

2) реєстрація, облік та оперативне оновлення інформації за всіма структурними блоками;

3) забезпечення оперативності отримання всієї необхідної інформації у вигляді звітів, довідок тощо для прийняття рішення з різних питань з баз, що знаходяться на будь-якому відомчому рівні: республіканському, обласному, територіальному;

4) забезпечення доступу широкого кола користувачів до інформації, призначеної для поширення.

До складу інформації Держреєстру ЛЗ входять відомості про: торговельне, міжнародне непатентоване та синонімічне найменування лікарського засобу; його виробника; хімічну назву та склад, фармакологічну дію та фармакотерапевтичну групу, показання, протипоказання, запобіжні заходи, взаємодію з іншими лікарськими засобами та побічну дію; форму випуску, спосіб застосування та дози, умови і строки зберігання та умови відпуску; дату і номер наказу MO3 про реєстрацію, а також інша інформація, необхідна суб'єктам фармацевтичного ринку [3].

Моніторинг цін на лікарські засоби система проводить за видами цін, що включають міжнародні; CIP (іноземні представництва); оптові (оптові фірми); роздрібні (аптечні організації).

Як вже зазначалося, інформаційний обмін між компонентами системи повинен здійснюватися за допомогою компонент Сервера об'єктів в єдину інформаційну систему охорони здоров'я (ЄICO3).

Зазначимо, що сервер об'єктів буде виконувати ряд базових функцій і дозволить реалізувати в зв'язці 3 
Сервером додатків і Сервером баз даних розподілений збір і зберігання даних медичної інформаційної системи (МIC).

Сервер об'єктів забезпечує виконання декількох функцій. Перша функція - забезпечення уніфікованого програмного інтерфейсу для клієнтських застосувань при маніпулюванні властивостями об'єктів в процесі введення і редагування даних, розташованих на сервері баз даних у вигляді сукупності пов'язаних нормалізованих таблиць. При цьому необхідно забезпечити незалежність сервера об'єктів від конкретного використовуваного сервера баз даних. Це дозволить на різних рівнях системи вибирати оптимальне за вартістю і продуктивністю середовище для зберігання і обробки даних.

Сервер об'єктів повинен мати можливість гнучко го нарощування і змінення структури об'єктів на усіх рівнях ієрархії й автоматичного тиражування змін на потрібні рівні, залежно від відповідних налаштувань.
Крім того, сервер об'єктів забезпечує унікальну системну (внутрішню) ідентифікацію за усіма рівнями ієрархії для тих об'єктів, для яких це необхідно, і тиражування інформації про всі об'єкти за усіма рівнями ієрархії.

Друга функція - розподілене тиражування конфігурації об'єктів, конфігурації баз даних (групи таблиць для зберігання інформації про об'єкти системи) і самих даних між вузлами системи, об'єднаними в ієрархічну мережу. Функції тиражування повинні виконуватися сервером об'єктів без необхідності постійного з'єднання між серверами різних вузлів, шляхом обміну файлами за допомогою електронної пошти або на фізичних електронних носіях.

Накопичений за останні роки досвід показав, що неможлива взаємодія різних систем за відсутності єдиного стандарту повідомлень, що об'єднує різні системи в єдину розподілену мережу даних. А для забезпечення безперебійної роботи розподілених

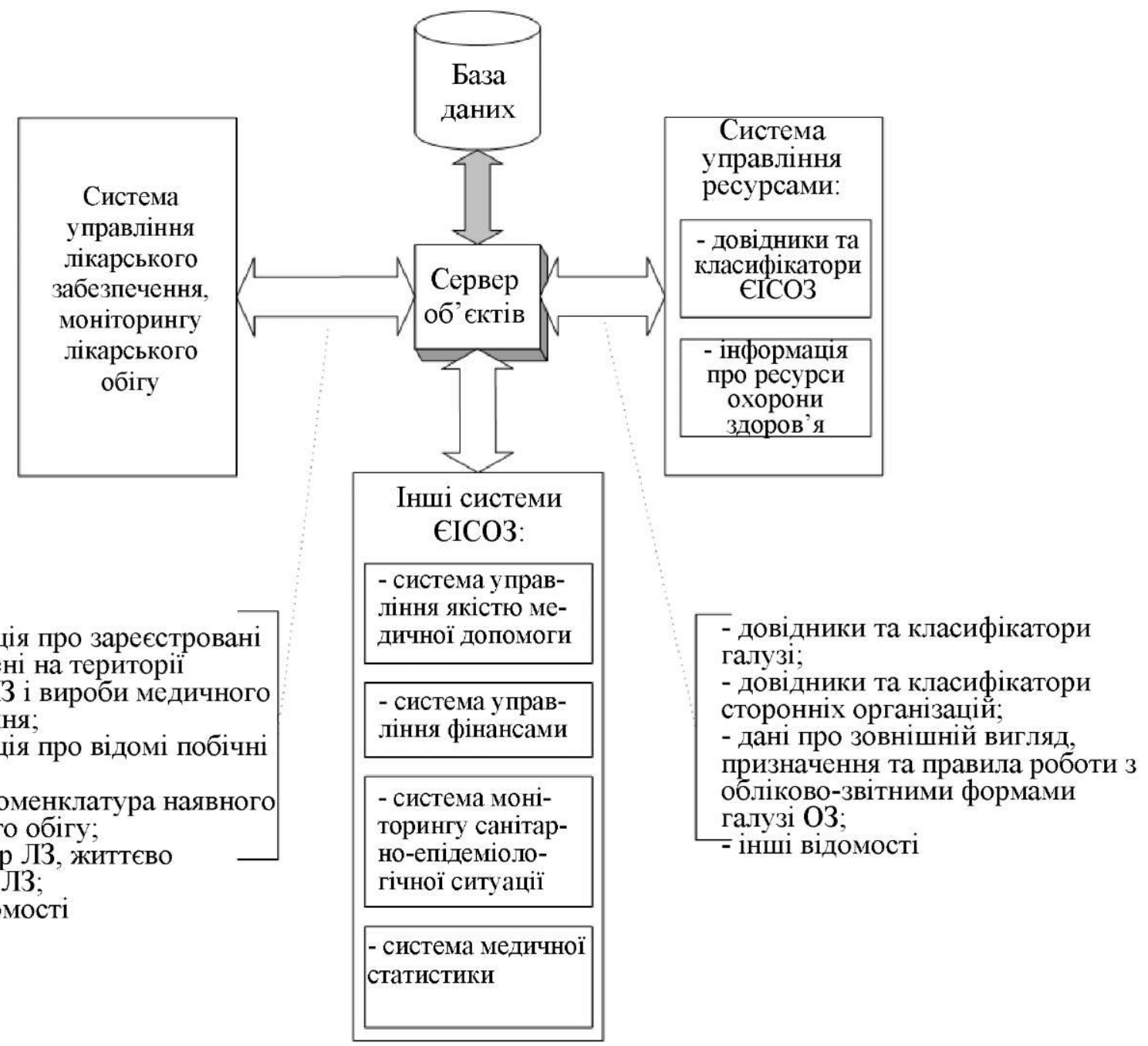

Puc. 1. Інформаційна взаємодія СУОЛЗ з іншими складовими єдиної інформаційної системи охорони здоров'я. 
об'єктів потрібен постійний стійкий зв'язок між ними, що підтримує технологія серверів повідомлень.

Інформаційна взаємодія ІСУОЛЗ з іншими інформаційними системами, діючими у рамках MIC, повинна здійснюватися шляхом обміну електронними повідомленнями по каналах зв'язку відповідно до протоколів, реалізованих на "сервері об'єктів", а також відповідно до регламентів, визначених договорами й угодами між державним замовником та організаціями-розробниками суміжних систем. Зрозуміло, що подібна взаємодія ІСУОЛЗ забезпечується за рахунок дотримання єдиних організаційних, методологічних і програмно-технічних принципів, насамперед шляхом уніфікації значень показників, що включаються у відомості про об'єкти обліку, на основі застосування єдиних класифікаторів і довідників, а також застосування для інформаційної взаємодії 3 суміжними інформаційними системами єдиних протоколів телекомунікаційних мереж, форм документів i форматів даних, що передаються на електронних носіях. Для всіх учасників інформаційного обміну системи за основу пропонується прийняти єдиний стандарт повідомлень - XML.

Зовнішніми інформаційними системами виступатимуть інформаційні підсистеми: медико-статистична; моніторингу санітарно-епідеміологічної ситуації; управління ресурсами тощо (рис. 1).

Функціонування системи повинно бути засновано на технології функціонування бізнес-процесів, реалізація яких об'єднає в єдине ціле учасників системи, потік робіт, функції та виконавців цих функцій, а та-

\section{Лтература}

1. Концепція розвитку фармацевтичної галузі України // Аптека. - №> 513 (42). - 31.10.2005.

2. Про затвердження Положення про Державний реєстр лікарських засобів / Постанова Кабінету Міністрів України від 31 березня 2004 р. № 411. - Режим доступу: http:// zakon.rada.gov.ua/cgi-bin/laws/main.cgi?nreg=411-2004-\%EF. 3. Регулирование фармацевтического сектора в Европе: ради эффективности, качества и равенства : Серия публикаций Европейской обсерватории по системам здравоох- кож правила управління їх послідовністю. ІСУОЛЗ будується масштабованою, тобто підтримується як необмежена кількість користувачів, так і структурних одиниць. Система є комплексом взаємопов'язаних модулів, кожен з яких має своє функціональне призначення.

Реалізація запропонованої концепції системи повинна забезпечити ефективне виконання завдань щодо регулювання та контролю в області забезпечення й обігу лікарських засобів на основі застосування сучасних комп'ютерних та інформаційних технологій, а також ефективного моніторингу й оперативного прийняття управлінських рішень на основі аналізу накопиченої інформації, здійснення повною мірою контрольно-наглядових функцій за фармацевтичною діяльністю аптечних і медичних організацій.

Висновки. 1. Створення та впровадження інформаційної системи управління обігом лікарських засобів є одним із важливих елементів моніторингу та регулювання фармацевтичного сектора охорони здоров'я. Система має забезпечити автоматизацію процесів управління забезпеченості лікарськими засобами, зокрема ведення реєстру лікарських засобів, державних формулярів, приписів тощо; взаємодію 3 різними організаціями, які працюють в галузі охорони здоров'я та за їі межами; облік закупівель і раціональне використання лікарських засобів на всіх рівнях надання медичної допомоги; моніторинг цін тощо.

2. Важливе об'єднання існуючих баз даних і тих, що розробляються, в інтегровану систему баз даних на основі єдиних державних і галузевих класифікаторів.

ранения / ред. Э. Моссиалос, М. Мразек, Т. Уолли. Copenhagen : the European Observatory on Health Systems and Policies, WHO, 2006. - 380 p.

4. Daniels N. Setting Limits Fairly? Can We Learn to Share Medical Resources? / N. Daniels, J. E. Sabin. - New York : Oxford University Press, 2002. - 347 p.

5. The world health report 2006: working together for health. Geneva : WHO, 2006. - 237 p. 